monia, electrolyzed with concordant percentage results. Platinum was constantly sought for but not found. The anodes were regularly weighed before and after their use, but showed no loss. Copper was successfully separated from iron-the quantity of the former being twice that of the latter. The same occurred when the quantity of iron greatly exceeded that of the copper.

UNIVERITY OR PENNSYlVANIA.

[CONTRIBUTION FROM THE JOHN HARRISON LABORATORY OF CHEMISTRY.]

\title{
ELECTROLYTIC DETERMINATIONS AND SEPARATIONS WITH THE USE OF A ROTATING ANODE'.
}

\author{
By JULia L,ANGNESS.
}

Received January 25, 1907.

The following paragraphs contain data obtained by the use of a rotating dish anode in the electrolysis of several metallic salt solutions. Curves accompany the various experiments to show more clearly the progressive deposition of metal.

The remarkably short period in which copper, silver, nickel and zinc are precipitated by the use of the dish anode leaves no doubt as to the superiority and advantage of electrolytic methods over ordinary gravimetric procedures.

The separations of metals, using the rotating anode, make the rapid methods even more useful. There seems little doubt but that in a short time many of the electrolytic separations now quite satisfactory with stationary electrodes will be further improved by the addition of conditions under which they can be executed with rotating anodes, using increased current and pressure, thereby decreasing the time factor to a minimum.

The spiral anode used and described by Exner has been employed in nearly all the work done in this laboratory on the rapid precipitation of metals in the electrolytic way.

It was with a view of still further reducing the time element that a new form of anode was devised, following a brief description of which, will be recorded a series of experiments illustrating its advantage over the older forms.

The new anode is a platinum dish of the same general form as the cathode (see Figure I). It is about $7 \mathrm{~cm}$. in diameter and $3 \mathrm{~cm}$. deep. Its sides are provided with ten slits perpendicular to the edge, each slit about $1.8 \mathrm{~cm}$. long, and $0.5 \mathrm{~cm}$. wide. These openings, together with a circular opening $1.3 \mathrm{~cm}$. in diameter in the bottom of the dish, insure free circulation of the liquid.

${ }^{1}$ From the author's Ph. D. thesis, I906. 
It is held in position by a stout platinum rod, and is so adjusted that it is equidistant from the sides of the cathode.

During the rotation of the anode the liquid is all contained within the space bounded by the cathode and the outer surface of the anode, no liquid remaining within the inner dish. It is, therefore, evident that the dilution in this case must be much less than when the spiral anode is employed. The volume of the electrolyte shonld not exceed 65 cubic centimeters.

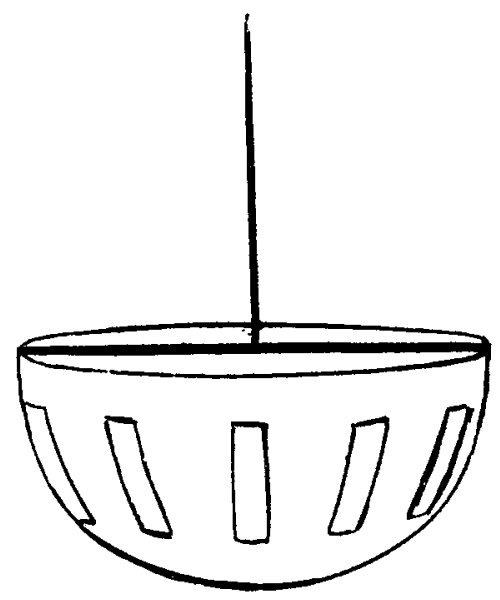

\section{Dish Anode.}

Fig. I.

When properly adjusted there is no splashing of the liquid and consequent loss of the electrolyte, as one might at first suppose there would be, nor is there any danger of incomplete precipitation due to liquid adhering to the inside of the anode, the decanted liquid showing no trace of the metal when subjected to tests.

\section{Determinations of Metals.}

Copper.

A solution of copper sulphate was prepared containing about 0.5035 gram of copper in $25 \mathrm{cc}$, and a series of determinations were made with the spiral anode (as described by Exner). The most satisfactory conditions for rapid precipitation were found to be as follows:

To $25 \mathrm{cc}$. of the copper sulphate solution add I cc. of sulphuric acid (dil. I : IO), I00 cc. of boiling water, and electrolyze: 


$\begin{array}{ccccc}\text { No. } & \text { Volts. } & \text { Amperes. } & \text { Time, mins. } & \begin{array}{c}\text { Wt. of Cu. } \\ \text { in grams. }\end{array} \\ \text { I } & \text { 10 } & 6-13 & 7 & 0.5038 \\ 2 & \text { 10 } & 5-13 & 7 & 0.5037 \\ 3 & \text { 10 } & 6-13 & 7 & 0.5034 \\ 4 & \text { 10 } & 5-13 & 7 & 0.5035\end{array}$

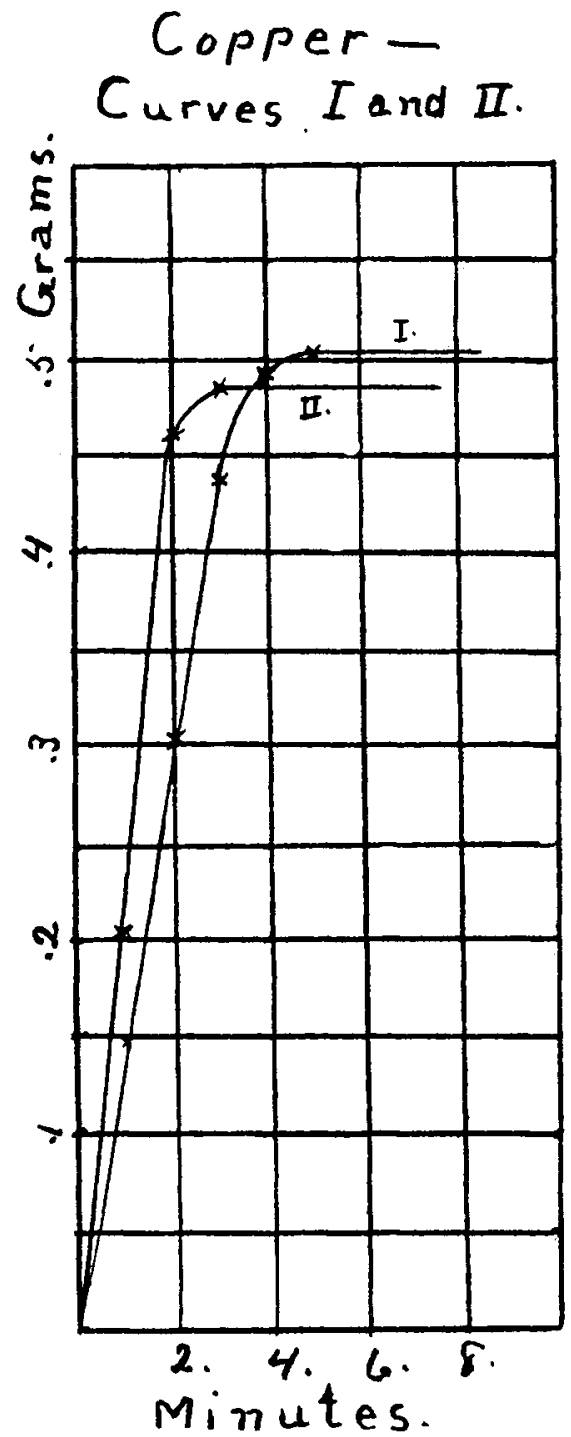

The perfectly adherent deposits were dark red in color, with a beautiful velvety appearance. 
Observing the above conditions the following time curve, (Curee, No. I) was determined:

$\begin{array}{cccc}\text { Amperes, } & \text { Time, mins. } & \text { Wt. of Cu } \\ \text { ingranis. } & \text { Ans } & 0.1493 \\ 10 & 5.6 & \text { I } & 0.3019 \\ \text { I0 } & 5.6 & 2 & 0.4371 \\ \text { 10 } & 5.6 & 3 & 0.4925 \\ \text { I0 } & 5.6 & 4 & 0.5029\end{array}$

Using the dish anode, with the same electrolyte, and diluting to about co cc., these results were obtained:

\begin{tabular}{|c|c|c|c|c|c|}
\hline No. & $\begin{array}{c}\text { Cu present } \\
\text { in grams. }\end{array}$ & rolts. & Amperes. & 'ine, mins. & $\begin{array}{l}\text { Wt of } \mathrm{Cu} \\
\text { in gtams. }\end{array}$ \\
\hline $\mathfrak{t}$ & 0.4884 & $7+$ & IO- I 5 & 4 & $0.488_{3}$ \\
\hline 2 & 0.4884 & 8 & $10-16$ & 3 & 0.4884 \\
\hline 3 & 0.4884 & $s$ & $10-16$ & 5 & 0.4887 \\
\hline 4 & 0.4884 & 8 & 10 & 2 & 0.4634 \\
\hline 5 & 0.4884 & 8 & IO & I & 0.2010 \\
\hline
\end{tabular}

The character of the deposit was the same as when the spiral was used. Curie II is constructed from these results.

When the spiral anode was used and nitric acid added as electrolyte, the best results obtained were those in which $1 / 2 \mathrm{cc}$. of the acid was added to $25 \mathrm{cc}$. of the copper sulphate solution, and the liquid diluted to $125 \mathrm{cc}$. with boiling water, $(25 \mathrm{cc}$. of the solution contained about 0.4876 gram of copper). Brilliant, crystalline, adherent deposits were obtained.

$\begin{array}{ccccc}\text { So. } & \text { volts. } & \text { Amperes. } & \text { Time, mins. } & \begin{array}{c}\text { Wt. of } \mathrm{Cu}_{11} \\ \text { in grants. }\end{array} \\ 1 & 8 & 7 & 15 & 0.4878 \\ 2 & 8 & 7 & 15 & 0.4877 \\ 3 & 8 & 8 & 15 & 0.4875 \\ 4 & 8 & 8 & 10 & 0.4875\end{array}$

The following time curve determinations show that ten minutes are required for complete precipitation.

\begin{tabular}{|c|c|c|c|c|}
\hline so. & Volts. & Amperes. & lime, mins. & $\begin{array}{l}\text { Wt. of } \mathrm{Cn} \\
\text { in grams. }\end{array}$ \\
\hline 1 & $s$ & $7-8$ & I & 0.1507 \\
\hline 2 & 8 & $7-10$ & 2 & 0.2518 \\
\hline 3 & $S$ & $7-11$ & 3 & 0.3418 \\
\hline 4 & $\$$ & 7-נ 1 & 4 & 0.3960 \\
\hline 5 & $s$ & $7 \cdot[1.5$ & 4 & 0.4486 \\
\hline 6 & $s$ & $7 \cdot 12$ & 6 & 0.4654 \\
\hline 7 & $\$$ & $7-12$ & 8 & $0.4 S_{52}$ \\
\hline 8 & 8 & $7 \cdot 12$ & 10 & $0.48-5$ \\
\hline
\end{tabular}

See Curze III for graphic representation.

Using the dish anode with the same electrolyte, the deposition of $0.48 \mathrm{I} 7$ gram of copper was complete in six minutes, with a pressure of 8 volts and if amperes. 
When $25 \mathrm{cc}$. of copper sulphate solution, containing 0.4967 gram of copper, to which was added I.2 grams of ammonium nitrate and $25 \mathrm{cc}$. of ammonia, were diluted to $125 \mathrm{cc}$, heated to boiling, and electrolyzed, complete precipitation, using the spiral anode, required about fifteen minutes, as per table below and Curie IV.

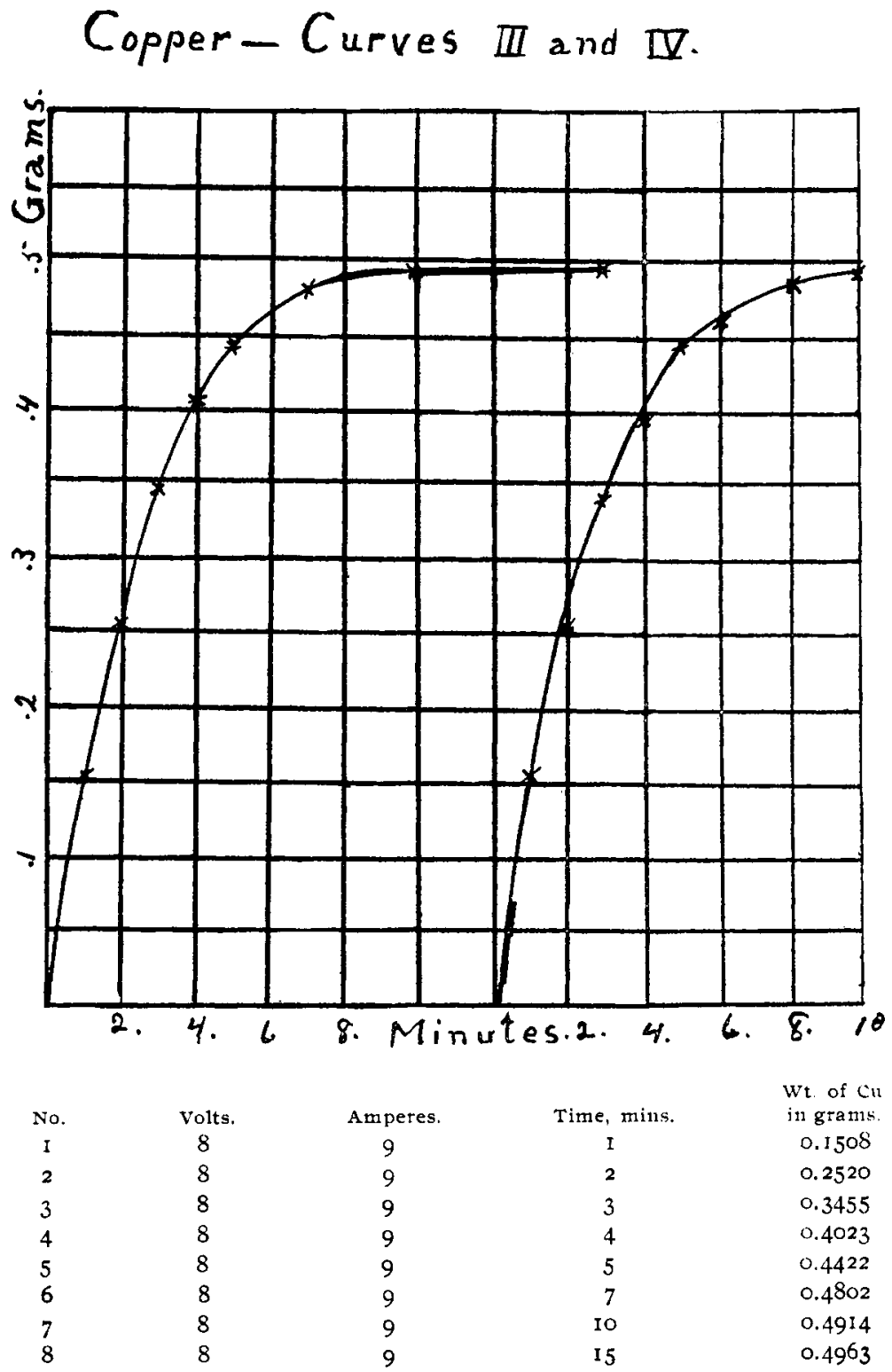


The deposits were bright and adherent.

With the same electrolyte 0.4824 gram of copper was deposited in six minutes with six volts and a current of I7 amperes, using the new anode.

The dish anode was also employed in depositing copper from a cyanide solution. A slight excess of potassium cyanide was added above that required to precipitate the copper and redissolve the precipitate. To that solution were added Io cc. of ammonia, and in six minutes, using 7 volts and I5 amperes, 0.4883 gram of copper was deposited in a beautifit burnished form.

\section{Silver.}

Silver gave the most satisfactory results. The silver from a nitrate solution was precipitated and redissolved in potassium cyanide, and an excess of two grams of potassium cranide added in each determination, the solution diluted as usual, heated almost to boiling, and electrolyzed.

The following table and corresponding curve (No. V) show results obtained by the use of the spiral anode.

\begin{tabular}{|c|c|c|c|c|}
\hline No. & Volts. & Amperes. & Time, mins. & $\begin{array}{l}\text { Wt. of } \mathrm{Ag} \\
\text { in grams. }\end{array}$ \\
\hline 1 & 5 & 2.8 & I & 0.2046 \\
\hline 2 & 5 & 2.8 & 2 & $0.339 \mathrm{I}$ \\
\hline 3 & 5 & 2.8 & 3 & 0.4858 \\
\hline 4 & 5 & 2.8 & 4 & 0.5043 \\
\hline 5 & 5 & 2.8 & 5 & 0.5225 \\
\hline 6 & 5 & 2.8 & 7 & 0.5270 \\
\hline 7 & 5 & 2.8 & 10 & 0.5301 \\
\hline
\end{tabular}

The precipitation was complete in ten minutes.

The deposits were chalk-white, and spongy in the bottom of the dish, but adherent. With the nez' anode, using a portion of the same solution, and adding three grams of potassium cyanide, the 0.53 gram of silver was leposited in two minutes, all but a very snall quantity of which was precipitated during the first minute. See Curie VI constructed from the results which follow:

\begin{tabular}{|c|c|c|c|c|}
\hline No. & volts. & Amperes. & Time, mins. & $\begin{array}{l}\text { Wt of Ag } \\
\text { in grams }\end{array}$ \\
\hline 1 & 5 & Io & 4 & 0.5304 \\
\hline 2 & 5 & 6 & 4 & 0.5306 \\
\hline 3 & 5 & 8 & 3 & 0.5306 \\
\hline 4 & 5 & 9 & 2 & 0.5304 \\
\hline 5 & 5 & 9 & I & 0.5116 \\
\hline
\end{tabular}

The great differences in current strength in the above series are due mainly to the variation in distance between the electrodes, a small decrease in clistance causing a large rise of the current. the pressure being kept constant. 


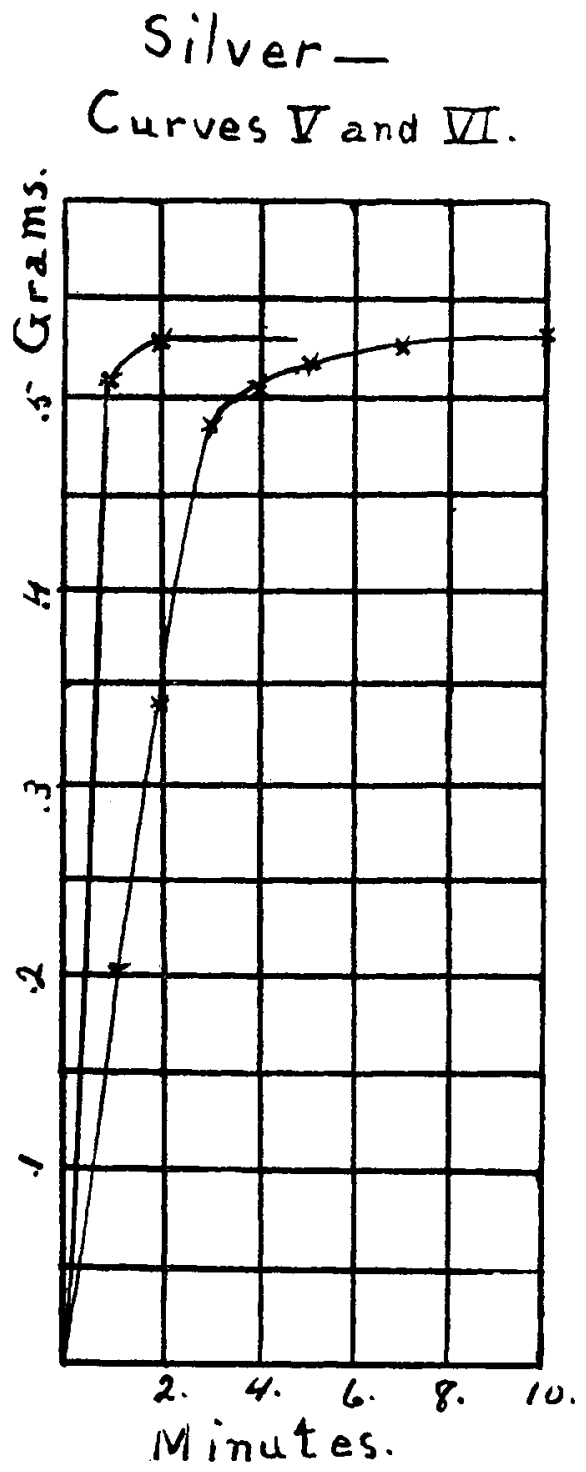

\section{Nickel.}

A few determinations of nickel from a solution containing ammonium sulphate show that half a gram of that metal may be precipitated in five minutes using the dish anode.

To $25 \mathrm{cc}$. of the nickel solution, containing 0.5004 gram of the metal, were added 3 grams of ammonium sulphate dissolved in water and $20 \mathrm{cc}$. 
of ammonia, the solution then diluted to $60 \mathrm{cc}$. and heated almost to boiling.

$\begin{array}{ccccc}\text { No. } & \text { Volts. } & \text { Amperes. } & \text { Time, mins. } & \begin{array}{c}\text { Wt. of Ni } \\ \text { it1 grams. }\end{array} \\ \text { I } & 6 & \text { II-I6 } & 6 & 0.5005 \\ 2 & 6.5 & \text { II-I4 } & 5 & 0.5002\end{array}$

Zinc.

This metal was also tried, and it was found that a quarter of a gram of the metal could be deposited in three minutes, using the dish anode, with the conditions indicated in Experiment No. 2.

\begin{tabular}{|c|c|c|c|c|c|}
\hline No. & $\begin{array}{l}\mathrm{NaOH} \\
\text { added. }\end{array}$ & Volts. & Amperes. & Time, mins. & $\begin{array}{l}\text { Wt. of } Z_{11} \\
\text { in stams. }\end{array}$ \\
\hline I & 5 grams & 5 & Io & 6 & 0.2472 \\
\hline 2 & ,. & 6 & I3 & 3 & $0.247^{6}$ \\
\hline 3 & 8 & 5 & 13 & 8 & 0.2472 \\
\hline
\end{tabular}

\section{Platinum.}

Platinum has long been known to be completely precipitated by means of the electric current, and, while the ordinary electrolytic methods for its cletermination are very satisfactory, they require considerable time,--four to five hours for the precipitation of 0.1 to 0.2 gram. By agitating the electrolyte, the complete deposition of the same amount may be accom-

\section{Platinum - \\ Curve VII.}

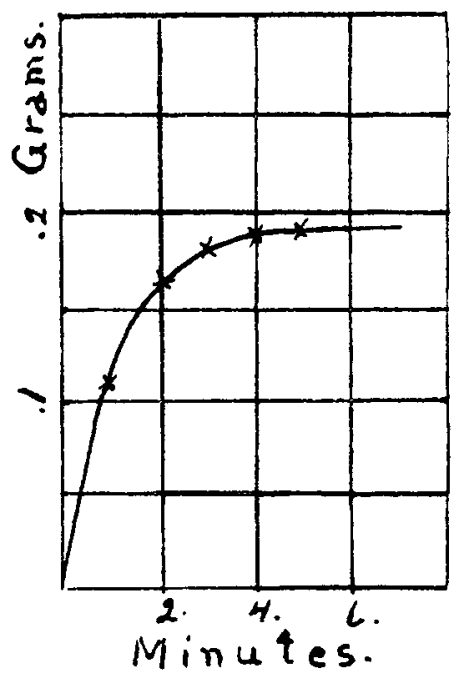

plished in a few minutes, as shown by the following experiments, in which a solution of potassium chloroplatinate was used, $25 \mathrm{cc}$. of the solution 
containing about 0.0953 gram of platinum. The metal was deposited on a silver-coated dish. The dish anode was employed and made to rotate during the electrolysis.

\begin{tabular}{|c|c|c|c|c|c|}
\hline No. & $\begin{array}{c}\mathrm{H}_{2} \mathrm{SO}_{4} \text { (dil. I:IO) } \\
\text { in c.c. }\end{array}$ & Voits. & Amperes. & Time, mins. & $\begin{array}{l}\text { Wt. of Pt. } \\
\text { in grams. }\end{array}$ \\
\hline I & 5 & 7 & I4 & 4 & 0.0956 \\
\hline 2 & 5 & 8 & I4 & 3 & 0.0907 \\
\hline 3 & 5 & 7 & I4 & I & $0.082 \mathrm{I}$ \\
\hline 4 & 5 & 5 & IO & 7 & 0.0953 \\
\hline 5 & 5 & 6 & 17 & 3 & 0.0932 \\
\hline 6 & 2.5 & Io & I6 & 3 & 0.0952 \\
\hline 7 & 2.5 & IO & 17 & 2 & 0.0926 \\
\hline
\end{tabular}

In numbers I, 4 and 6 the precipitation was complete. The deposits were dark gray in color and perfectly adherent. The great difference in voltage and amperage in the above experiments is due to variation in electrode distance.

Reproducing the conditions of 6 and 7 , doubling the amount of the solution, and diluting to $60 \mathrm{cc}$., the following experiments gave the results from which Curve No. VII was constructed.

$\begin{array}{cccccc}\text { No. } & \begin{array}{c}\mathrm{H}_{2} \mathrm{SO}_{4}(\text { dil. } \mathrm{I} ; \mathrm{i} 0) \\ \text { in c.c. }\end{array} & \text { Volts. } & \text { Amperes. } & \text { Time, mins. } & \begin{array}{c}\text { Wt. of Pt. } \\ \text { ingrans. }\end{array} \\ \mathrm{I} & 2.5 & \text { Io } & \text { I6 } & 3 & 0.1855 \\ 2 & 2.5 & \text { IO } & \text { I } 8 & 4 & 0.1904 \\ 3 & 2.5 & \text { IO } & \text { I7 } & 5 & 0.1973 \\ 4 & 2.5 & \text { Io } & \text { I } 8 & 2 & 0.1734 \\ 5 & 2.5 & \text { Io } & \text { I } 7 & \text { I } & 0.1158\end{array}$

The platinum was completely precipitated in five minutes.

\section{Palladium.}

This metal was precipitated from a solution of palladammonium chloride, $\mathrm{Pd}\left(\mathrm{NH}_{3} \mathrm{Cl}\right)_{2}$. A quantity of the salt was dissolved in ammonia and diluted so that Io cc. of the solution contained about 0.268 gram of palladium.

The deposits were usually made on silver-coated dishes, and the rotating dish anode was employed.

To Io $\mathrm{cc}$. of the palladium solution were added $20 \mathrm{cc}$. of boiling ammonia, and the whole diluted to $60 \mathrm{cc}$. with boiling water and electrolyzed.

\begin{tabular}{|c|c|c|c|c|}
\hline $\begin{array}{l}\text { No. } \\
\text { I }\end{array}$ & $\begin{array}{c}\text { Volts. } \\
5-6\end{array}$ & $\begin{array}{c}\text { Amperes. } \\
2+\end{array}$ & $\begin{array}{l}\text { Time, mins. } \\
\quad \text { I } 8\end{array}$ & $\begin{array}{c}\text { Wt. of Pd, } \\
\text { in grams. } \\
0.2682\end{array}$ \\
\hline 2 & I I & 5 & IO & 0.2680 \\
\hline 3 & 17 & 7 & 5 & 0.2682 \\
\hline 4 & 17 & I0 & 3 & $0.267^{8}$ \\
\hline 5 & 17 & IO & 2 & 0.2678 \\
\hline 6 & 17 & 9 & I & 0.2476 \\
\hline 7 & I7 & I0 & 2 & 0.2683 \\
\hline 8 & 17 & IO & 2 & 0.2680 \\
\hline 9 & I7 & 10 & 2 & $0.268 \mathrm{I}$ \\
\hline
\end{tabular}


The precipitation was complete in all except the sixth experiment. The deposits were gray and perfectly adherent. In the last three the metal was

\section{Palladium- \\ Curves $\mathrm{DIII}$ and $\boldsymbol{X}$}

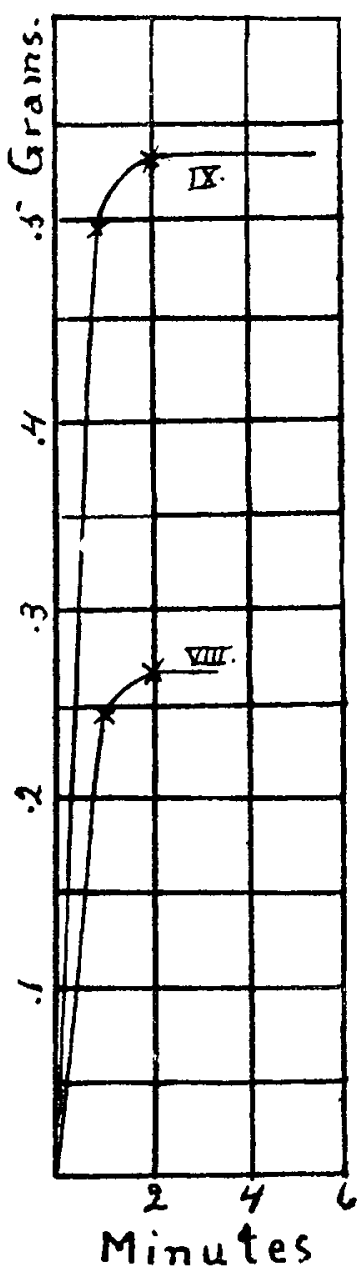

deposited directly on the platinum dish, and was removed by a warm mixture of chromic acid and potassium chloride.

Another series of determinations was made by doubling the amount of the palladium solution. 


$\begin{array}{cclcccc}\text { No. } & \begin{array}{c}\mathrm{NH}_{4} \mathrm{OH} \\ \text { in c.c. }\end{array} & \text { Dilution. } & \text { Volts. } & \text { Amperes. } & \begin{array}{c}\text { Time, } \\ \text { mins. }\end{array} & \begin{array}{c}\text { Wt. of Pd. } \\ \text { in grams. }\end{array} \\ \text { I } & 20 & 60 \text { c.c. } & 15 & 14 & 3 & 0.5358 \\ 2 & 20 & 60 \text { c.c. } & 17 & 14-20 & 2 & 0.5357 \\ 3 & 20 & 60 \text { c.c. } & 17 & 14-20 & 1 & 0.4966\end{array}$

These determinations of palladium speak for the accuracy of the method. With no other metal does the rapid electrolytic determination give more satisfactory results. The character of the deposit is excellent, the time element almost annihilated, and the range of conditions within which the complete precipitation is possible, is large; a high current, however, being necessary for the speediest deposition. Curves VIII and IX were constructed from the preceding data. Another series of experiments in which no ammonia was added also resulted well as to time and character of deposits.

\section{Rhodium.}

The rapid precipitation of rhodium was found to be best accomplished from a solution of sodium rhodium chloride, $\mathrm{Na}_{2} \mathrm{RhCl}_{6}$, to which a few drops of sulphuric acid had been added.

See Curve $X$ for plotted results.

$$
\begin{aligned}
& \text { Rhodium } \\
& \text { Curve } \mathbf{X} \text {. }
\end{aligned}
$$

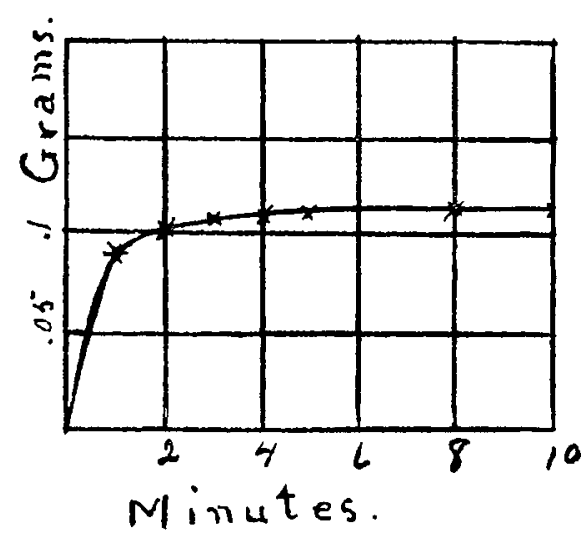

In the first four determinations Io cc. of the rhodium solution (about 0.0576 gram of rhodium), acidified with $2.5 \mathrm{cc}$. of sulphuric acid (dil. I : ro), were diluted to $105 \mathrm{cc}$. with boiling water, and electrolyzed, using a spiral anode; while in the last three, using the dish anode, the solution was diluted to about $60 \mathrm{cc}$. The metal was deposited on a silver-coated dish. 


\begin{tabular}{|c|c|c|c|c|}
\hline No. & Volts. & Amperes. & Time, mins. & $\begin{array}{l}\text { Wt of } \mathrm{kh} \text {. } \\
\text { in grams }\end{array}$ \\
\hline$I$ & 7 & 8 & I 5 & 0.0577 \\
\hline 2 & 7.5 & 8 & ro & 0.0580 \\
\hline 3 & 8 & 9 & Io & 0.0575 \\
\hline 4 & 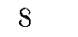 & 9 & 7 & 0.0576 \\
\hline 5 & S & 15 & 4 & 0.0573 \\
\hline 6 & 6 & II & 4 & 0.0563 \\
\hline 7 & 7 & I 4 & 4 & 0.0567 \\
\hline
\end{tabular}

In all but the sixth and seventh experiments the precipitation was complete. The deposits were adherent and almost black in color.

Doubling the quantity of the rhodium solution the following time curve determinations were made using the dish anode.

$\begin{array}{ccccc}\text { vo. } & \text { volis. } & \text { Amperes. } & \text { Time, mins. } & \text { Wt. of Rh. } \\ \text { ingrams. } \\ \text { I } & 7 & 15 & 1 & 0.0896 \\ 2 & 7 & 15 & 2 & 0.1006 \\ 3 & 7 & 15 & 3 & 0.1104 \\ 4 & 7 & 15 & 4 & 0.1128 \\ 5 & 7 & 15 & 5 & 0.1141 \\ 6 & 7 & 15 & 8 & 0.1152 \\ 7 & 7 & 15 & \text { IO } & 0.1153\end{array}$

\section{SEPARATIONS.}

\section{Gold from Platinum.}

As the cyanide electrolyte affords a means of separating gold from platinum, it was thought probable that a rapid separation night be possible from the same electrolyte. In the following determinations $5 \mathrm{cc}$. of gold chloride solution, containing about 0.0462 gram of gold, and $25 \mathrm{cc}$. platinum solution, containing about 0.094 gram of platinum, were employed. A spiral anode was used. The solution was diluted to about i 25 cc. and heated almost to boiling in each case.

$\begin{array}{cccccccc}\text { No. } & \text { Au Sol. } & \text { Pt. Sol. } & \text { KCy } & & & \\ \text { in cc. } & \text { in cc. } & \text { in grans, } & \text { Volts. } & \text { Amperes, Time, mins. Wt. of All } \\ 1 & 5 & \text { IO } & \text { I.5 } & 6 & 2 & 15 & 0.0464 \\ 2 & 5 & \text { IO } & 1.5 & 6 & 2 & 20 & 0.0462 \\ 3 & 5 & \text { IO } & 2 & 6+ & 2.5 & 12 & 0.0464 \\ 4 & \text { IO } & 25 & 2 & 6 & 2.5 & 20 & 0.0931 \\ 5 & \text { IO } & 25 & 2 & 6 & 2.5 & 15 & 0.0930 \\ 6 & \text { IO } & 25 & 2 & 6 & 2.5 & \text { JO } & 0.0932 \\ 7 & 20 & 25 & 2 & 6 & 2.5 & 15 & 0.1863\end{array}$

Gold from Palladium.

Gold was separated from palladium from a cyanide solution containing about equal amounts of the two metals. The solution was diluted to I25 cc. with boiling water and electrolyzed. The following three determinations show satisfactory conditions for the separation. 


$\begin{array}{ccccccc}\text { So. } & \text { Au sol. } & \text { KCN } & & & & \\ \text { in cc. } & \text { in grams. } & \text { Volts. } & \text { Amperes. } & \text { Time, mins. } & \text { Wt. of Aut } \\ \text { I } & 5 & \text { I } & 6 & 2 & \text { IO } & 0.0464 \\ 2 & 5 & 1 & 6 & 2 & 30 & 0.0462 \\ 3 & \text { IO } & 1.5 & 6 & 2 & 30 & 0.0932\end{array}$

\section{Copper from Platinum.}

A series of determinations showed that copper can be precipitated free from platinum in a solution containing the two metals, when 3 grams of potassium cyanide and 10 to $20 \mathrm{cc}$. of ammonia are added. When the ammonia was omitted a faint trace of platinum was deposited with the copper.

$\begin{array}{ccccccccc}\text { No. } & \begin{array}{c}\text { Cu Sol. } \\ \text { in cc. }\end{array} & \begin{array}{c}\text { Cu present } \\ \text { in grams. }\end{array} & \begin{array}{c}\mathrm{KCN} \\ \text { in grams. }\end{array} & \begin{array}{c}\mathrm{NH}_{4} \mathrm{OH} \\ \text { in }\end{array} & \text { volts. } & \text { Amperes. Time, mins. Wt. of Cu } \\ \text { I } & \text { IO } & 0.1290 & 3 & 10 & 5 & 3.5 & 35 & 0.1290 \\ 2 & \text { IO } & 0.1290 & 3 & 10 & 5 & 3 & 30 & 0.1295 \\ 3 & \text { IO } & 0.1290 & 3 & 20 & 5 & 3 & 30 & 0.1291 \\ 4 & \text { IO } & 0.1290 & 3 & 20 & 5 & 3 & 60 & 0.1294\end{array}$

In the fourth determination, in which the current was passed through the solution for a whole hour, a very slight trace of platinum was detected in the deposit.

\section{Silver from Platinum.}

This separation is best accomplished from a solution containing I.5 grams of potassium cyanide. The silver present in solution in the following determinations was 0.1183 gram.

$\begin{array}{ccccc}\text { No. } & \text { Volts. } & \text { Amperes. } & \text { Time, mins. } & \text { Wt. of Ag } \\ 1 & 3 & 0.25-0.05 & 20 & 0.118 \mathrm{I} \\ 2 & 3 & 0.25-0.05 & 20 & 0.1180 \\ 3 & 3 & 0.25-0.05 & 25 & 0.1180 \\ 4 & 3 & 0.25-0.05 & 20 & 0.1182 \\ 5 & 3 & 0.25-0.05 & 20 & 0.113^{8}\end{array}$

\section{Silver from Copper.}

It was found that silver and copper may be separated with ease from a cyanide solution by means of the rotating anode. Two grams of potassium cyanide should be added.

\begin{tabular}{|c|c|c|c|c|}
\hline No. & Volts. & Amperes. & Time, mins. & Wt. of Ag \\
\hline I & 2.5 & $0.35-0.1$ & I5 & 0.1184 \\
\hline 2 & 2.5 & $0.4-0.1$ & 20 & O. II 84 \\
\hline 3 & 2.5 & $0.4-0.1$ & 20 & O. I I 83 \\
\hline
\end{tabular}

\section{Silver and Copper from Platinum.}

From a mixture of the three metals, in a solution containing 2 grams of potassium cyanide, the silver may first be removed and then the copper. In each of the following experiments the solution contained about O.I3I4 gram of copper and O.II83 gram of silver.

$\begin{array}{cllcl}\text { No. } & \text { Volts. } & \text { Amperes. } & \text { Time, mins. } & \text { Wt. of metal found } \\ \text { I } & 2.5 & 0.40-0.08 & \text { I5 } & \text { o. I } 83 \text { g. silver } \\ & 5 & 3 & 35 & \text { 0.I3II g. copper } \\ 2 & 2.5 & 0.45-0.08 & \text { I5 } & \text { 0.II82 g. silver } \\ & 5 & 3 & 35 & 0.1320 \mathrm{~g} \text {. copper }\end{array}$


The silver deposits were free from copper and the copper deposits showed no trace of silver or platinum.

\section{Silver from Nickel.}

Two separations were made from solutions containing I.5 grams of potassium cyanide.

$\begin{array}{ccccc}\text { No. } & \text { Volts. } & \text { Amperes. } & \text { Time, mins. } & \text { Wt. of Ag. } \\ \text { I } & 2.5 & 0.4^{-0.07} & 20 & 0.1184 \\ 2 & 2.5 & 0.4^{-0.07} & 20 & 0.1185\end{array}$

\section{Silver from Zinc.}

A solution of the two metals containing 2.5 grans of potassium cyanide was used. Only two determinations were made.

$\begin{array}{ccccc}\text { No. } & \text { Volts. } & \text { Amperes. } & \text { Time. mins. } & \text { wt. of Ag. } \\ \text { I } & 3 & 0.35-0.08 & 20 & 0.1187 \\ 2 & 3 & 0.3 & 20 & 0.1185\end{array}$

\section{Silver from Copper in Coin.}

The ease with which silver may be separated from copper by means of the rotating anode suggested the rapid analysis of a silver coin by the same method.

A dime was cleaned and cut into four parts. One part was then weighed (0.7070 gram), dissolved in the least possible amount of nitric acid, the excess of acid evaporated, and the residue dissolved in water and diluted to $100 \mathrm{cc}$. To $25 \mathrm{cc}$. of this solution was added $\mathrm{I} / 2$ gram of potassium cyanide. The silver was first removed with a low current, and the decanted liquid after evaporation electrolyzed for the copper. The conditions and results obtained are tabulated below.

$\begin{array}{cclcc}\text { No. } & \text { volts. } & \text { Amperes. Time, mins. } & \text { wt. of metal. } \\ \text { I } & 3^{-2.5} & 0.4-0.06 & 35 & 0.1539 \mathrm{~g} . \mathrm{Ag} \\ & \text { Io } & 5 & \text { IO } & 0.0177 \mathrm{~g} \text {. Cu } \\ 2 & 3^{-2.5} & 0.4-0.06 & 45 & 0.1588 \mathrm{~g} . \mathrm{Ag} \\ & \text { Jo } & 6 & \text { Io } & 0.0180 \mathrm{~g} . \mathrm{Cu}\end{array}$

$\tau_{c}$ of metal. $89.90 \%$ silver Io.01\% copper $89.84 \%$ silver Io.18\% copper

The complete analysis, including the weighing of the coin and the final weighing of the deposits, required about two and a half hours.

If two portions are taken, depositing the metals together in the one, and the silver alone in the other, the complete analysis can be made in an hour and a haif, providing two dishes are available. One determination was made in that way. The coin weighing 0.5638 gram was dissolved in a small amount of nitric acid (less than $I \mathrm{cc}$.). The excess of acid was evaporated. Two grams of potassium cyanide were then introduced and the solution diluted to $100 \mathrm{cc}$. $25 \mathrm{cc}$. of this solution diluted to about 125 cc. were electrolyzed for the silver and copper combined, and a second portion for the silver alone.

$\begin{array}{cccl}\text { Volts. } & \text { Amperes. } & \text { Time, mins. } & \\ 7 & 0.2 & \text { I } & 0.1409 \text { combined wt. of Cu and Ag } 99.94 \% \\ 2.5 & 0.5-0.07 & 25 & 0.1268 \text { weight of silver }\end{array}$

VNIVERSTY OF PENNSYLVANia. 